\title{
The Impact of Scandalous News in the Automobile Manufacture on Companies from the Same Industry: A Comparative Study on the Chinese and European Markets
}

\author{
Anastasia Mews, $\mathbf{M A}$ \\ Shanghai University, China
}

Doi:10.19044/esj.2021.v17n23p67

Submitted: 22 June 2021

Accepted: 06 July 2021

Published: 31 July 2021
Copyright 2021 Author(s)

Under Creative Commons BY-NC-ND

4.0 OPEN ACCESS

Cite As:

Mews A. (2021). The Impact of Scandalous News in the Automobile Manufacture on Companies from the Same Industry: A Comparative Study on the Chinese and European Markets. European Scientific Journal, ESJ, 17(23), 67.

https://doi.org/10.19044/esj.2021.v17n23p67

\section{Abstract}

This paper examines the effect of scandalous news on corporate reputation of rival firms from the same industry and investigates the effects' differences in China and in Europe, providing evidence that scandalous news influences not only the target company itself, but also other companies from the industry. For this purpose, the paper uses the 2015 Volkswagen emissions scandal as a natural experiment. Volkswagen, BMW, Mercedes-Benz, Audi and Porsche were selected as sample companies. To measure reputational spillover effects, cumulative abnormal stock returns and sales growth of the sample companies are calculated and compared before and after the announcement of the scandal. The methodology adopted for estimating stock returns is the event study method, which measures the impact of a specific event on the value of a firm. Stock price data is collected from Bloomberg and used to calculate cumulative abnormal returns of the sample companies. Furthermore, difference-in-differences estimation is used to compare the sample companies' sales growth before and after the scandal. Volkswagen, Audi, BMW and Mercedes-Benz are included in the treatment group, whereas 29 non-German car manufacturers were selected as the control group. The results show that overall rival companies were affected by the scandal, cumulative abnormal returns declined by $6 \%$ and $10 \%$ for BMW and Mercedes-Benz respectively, showing the contagion effect. However, the sales growths of these two manufacturers greatly increased, specifically on the 
Chinese market for Mercedes-Benz and on the European market for BMW, proving dominance of the competitive effect and differences of the reputational spillover effects across countries.

Keywords: Volkswagen emissions scandal; event study; reputation; competitive effect; contagion effect

\section{Introduction}

Corporate reputation is not easily imitated by competitors and has become one of the most valuable intangible assets of successful companies. Corporate reputation research has a strong appeal in both the academic and business worlds. The exposure of a scandal is likely to affect not only the company involved, but also the entire industry.

If a company takes an action that damages its reputation, how does that action reflect upon other companies within the industry? Will the rival firms receive a loss due to shared reputation or will they take the advantage of the weakness of their competitor? This paper examines the effects of reputation spillover between rival firms. For this purpose, the event study method is chosen, using the 2015 Volkswagen emissions scandal as the natural experiment.

Volkswagen Emissions Scandal shocked the whole automotive industry in 2015. As nowadays sustainability and ecology are one of the main concerns of human society, the Environmental Protection Agency (EPA) tightens emission control due to harmful and mortal effects of nitrogen oxide which is a pollutant found in car's exhaust. Volkswagen, as one of the leading automobile manufacturers in the world, attempted to take over the United States diesel market. Most of the competitors, such as Honda, Hyundai, Nissan, found the new regulations extremely challenging, Volkswagen, on the other hand, showed great success (Mansouri, 2016). Surprisingly, in September 2015 it was reported by EPA that in an ample number of Volkswagen vehicles, sold worldwide, a defeat device or software was embedded in the diesel engine with the purpose of changing vehicle performance to improve required results. Volkswagen aimed at pretending that its vehicles follow emission standards, but the actual result of the Volkswagen emission test on the road was thirty-five times more than the cheated result in the lab (Le Page, 2015). The Volkswagen emission test scandal has created dramatic consequences and has an impact on an ample number of authorities. Only in many years after this huge scandal more cases of emissions cheating in the automotive industry have been revealed, which makes the Volkswagen emissions scandal one of the severest cases of economic fraud ever - one with far-reaching economic-, social- and health-related consequences. Hence, it is 
an appealing natural experiment for testing shared reputation in German automobile industry.

Announcements of operational loss events tend to cause significant losses in the market value of that firm's equity, which potentially spills over to non-event firms. If a certain firm experiences negative consequences of its actions, competitive firms might either experience a negative effect as well, receiving a contagion effect, or it might show a quite opposite reaction -so called, competitive effect (Goins, 2008). These influences are also called 'spillovers'.

The aim of this paper is to examine the spillover effects of capital markets in two regions (China and Europe) before and after the disclosure of scandals, and to determine, whether there is a "contagion effect" or "competition effect", and which dominates. Despite the public attention to the negative effects of scandal disclosure, there is little research on the impact of contagion and competition effects. Most studies consider only the impact on the target firm, not the impact received by firms in the same industry. There have been studies that explore companies in the same industry in one country, but no studies that compare the effects received by companies in the same industry in two different countries. Therefore, this paper contributes to the literature by comparing the differences in spillover effects across countries. Consumers' psychology is different in China and in Germany, and the impact received by companies may not overlap. By studying the impact of scandals on stock prices and market reactions some lessons can be learned, providing references for other companies in the industry to address such issues in the future.

The rest of the paper is organized as follows: Section 2 discusses the emission scandal timeline; Section 3 provides a review on existing literature; Section 4 explains the event study method and data resources; Section 5 presents the empirical results and Section 6 concludes.

\section{Background: The Volkswagen Emissions Scandal}

\subsection{Timeline of the Scandal}

Diesel vehicles occupy a significant portion of the global automobile market, and due to their low price in Europe, Europe has become the largest market for diesel vehicles, and its passenger diesel vehicles account for more than sixty percent of the passenger vehicles in the whole European continent. In today's increasingly serious environmental pollution, the exhaust emissions from the use of diesel vehicles are undoubtedly the key control area of each country. "Clean" emissions have also become the focus of publicity in the sale of diesel vehicles (Mansouri, 2016).

In order to be ahead of the traditional German auto powerhouses such as Mercedes-Benz and BMW in the field of diesel car sales and occupy the 
European diesel car market, VW claims to have invested heavily in the research and development of clean diesel models a long time ago, resulting in the fact that the company's diesel vehicles are not only "clean" in terms of emissions but also efficient in terms of power.

In recent years, the U.S. regulatory system became much stricter than Europe in terms of diesel emissions regulations. Historically, the United States and European Union have taken different approaches to regulate passenger vehicle fuel economy and emissions of greenhouse gases and other pollutants, affecting choices of vehicle engines and fuels. In the U.S. emission regulations, the emission standards for gasoline and diesel vehicles are extremely severe (Klier, 2016). Such stringent tailpipe requirements mean more capital investment, which causes many car companies to be discouraged from the U.S. diesel market, resulting in passenger diesel vehicles in the U.S. passenger car market only accounting for two percentage points. It is not difficult to see that the whole diesel car market in the United States is in an undeveloped state, which makes it very attractive for the automobile manufacturers - the potential of the market is unlimited. Combined with its own brand image of reliability, durability and energy efficiency, Volkswagen has made its "clean diesel" vehicles, which have become the technology leader in the U.S. diesel vehicle segment.

In May 2014, a study of the Center for Alternative Fuels, Engines \& Emissions on behalf of the International Council on Clean Transportation (ICCT) was the beginning of the Volkswagen emissions scandal. According to the study, two Volkswagen diesel models greatly exceeded the U.S. emission limits when emissions were measured under real driving conditions, which was different from the laboratory tests. The Environmental Protection Agency (EPA) requested explanations from Volkswagen, but the company stated that this problem had already been solved. VW developed software patches for that purpose and recalled 500,000 cars. Nevertheless, the effect was too small to make a significant difference (EPA, 2015a). Consequently, the agency threatened VW not to certify Volkswagen's 2016 diesel models for sale in the U.S. unless Volkswagen could explain the test results and guarantee that new models would not exhibit the same discrepancies. On September 3, 2015, VW admitted to the EPA and CARB that they had used a defeat device in their software which regulated emissions and produced fake test results in the test box (EPA, 2015a).

The scandal entered its public phase on September 18, 2015, when the EPA served a Notice of Violation to the Volkswagen Group, stating that Volkswagen illegally installed defeat devices in approximately 480,000 2.0liter diesel cars from 2009 to 2015 (EPA, 2015a). On September 20, Volkswagen publicly admitted manipulations and apologized in a public statement (VW, 2015a). Shortly afterwards, Volkswagen disclosed that the 
defeat device was installed worldwide in about eleven million cars (VW, 2015b). In the following months, the EPA addressed a second Notice of Violation to Volkswagen, in which they alleged that also 3.0-liter diesel cars were affected (EPA, 2015b), including models of Audi and Porsche, which are subsidiaries of Volkswagen.

It is worth adding that this huge scandal was just the beginning of uncovering a whole series of violations, which occurred in numerous companies. Major automobile companies started recalling their cars voluntarily. In January 2017, Fiat Chrysler Automobiles received a Notice of Violation by the EPA regarding an installed defeat device; in March 2017, investigations on Daimler employees in the context of emissions cheating started with subsequent searches followed by a mandatory recall of more than 700,000 cars in Europe due to emissions cheating. Non-European car manufacturers were similarly covered in the media. Mitsubishi admitted to having cheated on emissions tests for the past 25 years. South Korean officials accused Nissan of utilizing defeat devices, and irregularities in Suzuki's emissions testing became public. High emission values were also reported for Mazda, Hyundai and Kia cars (Barth, 2019).

All these major events were triggered by the Volkswagen Emissions Scandal, and the consequences for the company were dramatic: resignation of the VW Chief Executive Officer Martin Winterkorn, financial losses of more than $\$ 18$ billion in fiscal year 2015, a civil settlement amounting $\$ 15$ billion to the USA. The scandal was covered by all the main news in different countries.

2.2 Why is the Volkswagen Emissions Scandal a suitable natural experiment

Car industry is one of the world's largest industries by revenue. Under the environment of increasingly mature market development and fierce competition in the automotive industry worldwide, car companies are chasing after greater benefits and seeking higher development. In such conditions there are numerous cases of worldwide scandals happening in the automobile industry in the past decades. What makes the Volkswagen Emissions Scandal a perfect natural experiment to analyse reputational spillovers?

First of all, the news broke out very unexpectedly and very fast, the society was shocked by what happened, and it immediately was shown by the company's stock price. Such a sudden event offered the researchers a great opportunity to study the effect of a certain event on the company's market value. Second, German vehicles take a large share of the automobile market worldwide. According to the German Center for Automotive Research (CAR), in 2020 China accounted for 38 percent of global car sales of Germany's largest car manufacturers Volkswagen, BMW and Daimler (Mercedes-Benz). Lastly, the scandal triggered a widespread public discussion, which makes 
country-related reputational spillovers more likely to occur. For the reasons described above, this paper selects a famous economic and social event of automobile manufacturing safety scandal for its study purpose, taking VW's Emissions scandal as the research event to explore in detail "contagion effect" and "competition effect" on the same industry automobile enterprises.

\section{Literature Review}

\subsection{Contagion Effect and Competition Effect}

Corporate Reputation is an important discussion topic, covered by large literature in various fields of study from marketing to the industrial organisation. Reputational spillover is the main subject of our interest in this research. Therefore, our research is related to a number of empirical studies examining the competitive effect and the contagion effect.

Among the events that were studied in the past, there is a big number of studies related to bankruptcy (Helwege and Zhang, 2015; Lang and Stulz, 1992), merger announcements (Akhigbe and Martin, 2000), dividend-related announcements (Laux et al., 1998; Slovin et al., 1999), new product introductions (Chen et al., 2005), layoff announcements (Goins and Gruca, 2008), stock price surprises (Akhigbe et al., 2015), stock split announcements (Tawatnuntachai and D'Mello, 2002), going-concern audit opinions (Elliott et al. 2006), operational losses (Eckert et al., 2020), and environmental violations (Bouzzine and Lueg, 2020; Barth et al., 2019).

One of the very first researchers to study contagion and competition effects, are Lang and Stulz (1992), using data from 1970 to 1989, they examine the industry effects of corporate bankruptcies in the United States. The results of their study show that the release of bankruptcy information leads to a negative impact on the stock prices of competing firms in the same industry and a general decline in their share prices, which confirms the existence of a contagion effect. On the other hand, in the industries with a high level of competition, other firms in the same industry are not significantly negatively affected, and some even gain from the event. This confirms the existence of the competition effect.

Slovin et al. (1999) consider the effects of dividend cuts on other banks in the same industry using data from U.S. money center banks and regional commercial banks. They study whether other banks in the same industry are affected by externalities when a bank cuts its dividend. They found that when the U.S. money center banks cut dividends, regional commercial banks are affected by the contagion effect due to this information. However, when regional commercial banks cut dividends, they only have a negative impact on themselves, while other regional commercial banks in the same geographic area are affected by the competitive effect. 
Elliott et al. (2006) use the returns from publicly-traded land subdivision/development firms and Real Estate Investment Trusts to examine whether intraindustry information transfers from going-concern audit opinion announcements create contagion or competitive stock price reactions for other real estate firms operating in the same line of business. As a result, they find a competitive effect dominating among rival firms.

It can be seen that many results show rather contradicting empirical results. Therefore, it is important to investigate the mechanisms, which allow one of the two effects to dominate.

Goins and Gruca (2008) explore the possibilities of reputational spillover effects, which might be positive and negative as well. The authors use rivel firms' stock prices as a company's market value unit, and longitudinal layoff announcements in the US oil and gas industry from 1989 to 1996 as a sample. They find that interorganizational reputation effects follow a contagious process, indicating negative response to a layoff announcement, containing negative news for the shareholders, and vice versa - positive news brings positive effect for the rival companies due to the contagion effect. According to this study, the similarity in matters such as reputation, market demand, public awareness, resources, third-party support, and platform ecosystems, creates head-to-head competition. Goins and Gruca also find that close rivals receive both contagion and competitive effects. Although the contagion effect dominates, its scale is reduced by the competitive advantages (or disadvantages).

To understand what are the driving mechanisms of contagion and competition effects, Xie et al. (2019) consider the "net effect" of reputational spillover. A rival firm experiences both, the contagion effect (stock prices of competitors move in the same direction), which affects all the competitors in the industry at the same time, and competitive effect (stock prices of competitors move in the opposite direction), led by firm-specific information. Xie et al. (2019) argue that the net effect (the relative importance of competitive effect to contagion effect) depends on two factors: the relative size of intra-industry competitors and the type of information spilling over the social media. Hence, according to competition level, close and distant competitors against an industry leader experience high competitive effects, while moderate competitors experience high contagion effects.

Small firms need constant innovations to survive in the market and are more vulnerable to industry leaders' challenges (Chen et al., 2005). Hence, distant competitors are expected to react more strongly to industry leaders' valuation changes as well. Both. Goins (2008) and Wu (2019) agree close competitors are likely to receive competitive effect. However, Ouyang et al. (2020) argue that stakeholders tend to categorise firms by similarities (firm size, country of origin, industry etc.), therefore, risk of contagion effects are 
higher for similar firms. In other words, German automobile manufacturers are more exposed to receiving negative reputational spillover effects of the Volkswagen Emissions Scandal.

Akhigbe et al. (2015) have also studied the reasons why one effect might dominate. They argue that a pronounced stock price decline of one firm yields negative valuation effects for industry rivals due to the degree of the surprise, characteristics of the firm experiencing the negative surprise (such as its relative size), characteristics of the rival firms (such as their similarity to the firm experiencing the negative surprise), and characteristics of the corresponding industry (such as degree of concentration).

Barth et al. (2017) conducted an event study on the Emissions Scandal, considering not only stock prices, but also bond and credit default swap (CDS) data. They found significant financial losses for Volkswagen as a reaction of the market on poor environmental violations of the company. Bouzzine and Lueg (2020) extend the study by considering a longer time period and multiple events in their research. Considering 10 identified Dieselgate-related events, they found a significant contagion effect on rival firms, which appeared to be larger than in an individual sale of VW's stock.

Wood et al. (2018) observed abnormal stock returns to 41 environmental violations announcements. They find that the announcements occurring after the Emissions Scandal are all associated with a more negative stock market reaction than those occurred before the scandal. These results indicate that consumer's confidence was shaken, and investors' risk aversion increased after the Dieselgate case.

This paper aims to investigate the reputational spillover effect triggered by the Volkswagen Emissions Scandal on German rival firms in Europe and in China. It is assumed that due to the market differences and consumer psychology, the two countries might show different reactions to the negative news.

\subsection{Corporate Reputation in China}

Many researches have been published about the methods of measuring a firm's reputation. The papers discussed above mostly focus on a company's market value, demonstrated by its stock returns. However, a few other ways have been developed to examine corporate reputation, focusing more on the social aspects of a company's reputation.

Schweiger (2004) proposed a concept for measuring corporate reputation, referring to reputation as an attitude construct that implies splitting it into affective and cognitive components.

Pappu et al. (2007) report a hierarchy observed among three countries in terms of respondents' product-category country associations. Japan, Germany, USA, Australia, and Italy are the top five countries respondents associate with 
cars. It shows that consumers in China put a higher value on German brands compared to European ones, which also might influence a reputational spillover outcome in China.

An alternative way to measure corporate reputation was proposed by Rust et al. (2021) using social media. They developed a reputation tracker based on brand reputation driver and sub-driver data, for 100 top global brands, using Twitter tweets method. The tracker is highly time-sensitive and context-specific, it allows firms to respond fast to market stimuli.

Zhang (2009), inspired by the work of Schweiger, extends the model to different countries with different cultures. Since China is becoming an indispensable part of the world market, and because ever more foreign companies are entering this market, corporate reputation management in China seems promising. Together Zhang and Schweiger (2009) conduct an empirical study in the Chinese context to show the applicability of the model in China as well. They find that in European countries and in the US quality, performance and attractiveness are the main positive factors regarding a firm's reputation. However, performance is the number one reputation driver in China. In China, good performance could simultaneously and effectively lead to strong likeability and competence of corporate reputation. Responsibility as the second strongest driver of corporate reputation is definitely becoming more and more important to strengthen a company's standing in China. From here it is possible to conclude that corporate responsibility plays an even more important role on Chinese market. Events connected with a company's social responsibility might strongly influence a firm's reputation in China.

Following Zhang (2009) and Schweiger $(2009,2004)$ this paper assumes that reputational spillover effects might differ, not only depending on the company's features and competitive abilities, but also on geographical factors as well.

\subsection{Automobile market in Europe and in China}

Automobile industry is one of the largest and most competitive industries, which constantly changes due to new policies, business environment and innovative technology.

The European automobile industry has its special features, such as high level of technology, importance of safety, sensitivity to the environment. Although Europe is a traditional car producer and an important region of automobile industry, constantly emerging Asian competitors cause decline of the European share in global car production (Vošta et al., 2017). European automobile market is different from the Chinese market. Consumer's need and demand created separate market segments for electric cars, diesel-powered cars, sport, racing, and luxury vehicles, which led to technological and industrial developments in the industry. Whereas, Chinese market was always 
attractive for foreign manufacturers due to its low labour cost and tariff, generating foreign investments (Joshi, 2019). Moreover, the demand for cars in China greatly increased after the reform and open policy. Local manufacturers, undeveloped at that time, could not meet customer's needs, which offered new opportunities for foreign companies. The Volkswagen Company is one of the earliest manufactures set up business in China, being rather successful up till now and selling on the Chinese market more than on its home market in Germany. The reasons for that are Volkswagen's good reputation in China and high demand for practical, daily use cars. Meanwhile, the number of car manufacturers in China is very high, however, the majority of these companies are unknown abroad (Zhao et al., 2009). Despite a large number of local Chinese automobile manufacturers and foreign investors being obliged to produce in joint ventures with Chinese partners, foreign brands still capture almost $60 \%$ of the market. It results from the fact that Chinese cars are aimed at consumers with low purchasing power, and premium cars, which command a large share of the Chinese market, are almost exclusively manufactured with foreign technologies. The production of luxury cars is rather stable and resistant to economic fluctuations, with a strong brand loyalty playing a great role as well. The biggest premium manufacturers, BMW, Daimler, Audi, show a very dynamic production in China and in Europe.

An additional challenge for car manufacturers is local policies and regulations. European policies are driven by internationalization and the free market. The aim of the EU is to maintain a world-class automobile industry producing the most energy efficient and safe vehicles and guarantee millions of highly skilled jobs. In order to achieve these objectives, the European Commission has created the CARS 2020 Action Plan aimed at strengthening the competitiveness and sustainability of this sector by 2020. To deal with exhaust emissions, alternative fuels, funding for research and development, improving road safety, and the development of intelligent transport systems, the European Commission proposed the "European Green Cars Initiative" framework. As the main concern is $\mathrm{CO} 2$ reduction, electromobility in Europe must come from renewable sources, which makes the task even more difficult for automobile manufacturers (Vošta et al., 2017). In contrast, in China urban air pollution is the most pressing environmental problem, and electromobility is therefore encouraged even if cars obtain their electricity from coal-fired power plants, as long as the emissions are kept away from the cities (Hu et al., 2018).

What governments are willing to subsidize can also influence the automobile industry in different markets. While China supports local manufacturers and consumers in producing and purchasing electroautomobiles, Germany subsidizes research rather than consumer uptake and 
leaves coordination to private-sector led initiatives. There are various other regulations in China that make it not easy for foreign manufacturers. For instance, limited vehicle licenses in major cities, non-transferable lotteries in Beijing or action systems in Shanghai. Besides that, China also has Corporate Average Fuel Consumption (CAFC) standards to control the official use of fuel intensity levels, designed to realize an ambitious average fuel consumption target of $6.9 \mathrm{~L} / 100 \mathrm{~km}$ by 2015 and of $5.0 \mathrm{~L} / 100 \mathrm{~km}$ by 2020 (Chen et al., 2020).

There is a constant race in the automobile industry to bring creative new formulas and ideas to improve the user experience and reduce environmental impacts. This research assumes that aside from the consumer's preferences, automobile market differences in China and Europe might also influence reputational spillover effects.

\section{Study Method}

\subsection{Hypothesis}

The goal of this investigation is to examine the specific effects of industry scandals on individual listed companies in the same industry. As it is established in the literature review, the effect might be divided into two directions: positive competitive effect and negative contagion effect. When a scandal occurs, the listed companies in the same industry experience a change in sales volume or revenue, share price or stock return. This paper's method is to calculate stock abnormal returns for each firm and sum them over time, and then to conduct a significance test. The following hypotheses are proposed:

$H_{0} H_{0}$ : The returns of individual stocks in the same industry are not affected at the time of the scandal.

$H_{1} H_{1}$ : The stock returns of the sample companies in the same industry were affected when the scandal occurred.

Under the null-hypothesis it is expected that the abnormal returns AR will be equal to zero. To test the null-hypothesis t-test method is used further in the empirical evidence section.

\subsection{Event Study}

Most of the related literature uses the event study method to investigate the firm's market value. MacKinlay (1997) offers a detailed and rather simple introduction to this method. Using financial market data, an event study measures the impact of a specific event on the value of a firm. The usefulness of such a study comes from the fact that, given rationality in the marketplace, the effects of an event will be reflected immediately in security prices by examining the extent to which the average or cumulative abnormal return 
CAR deviates from zero in a certain time interval before and after the event disclosure date in a specific event window.

The most successful area where the event study method has been applied is in the area of corporate finance. Event studies in this field are more focused on studies that examine abnormal returns before and after the first public announcement by a certain company, such as mergers, acquisitions, and refinancing decisions. The event study method is also very important to test the effectiveness of capital markets. Stock market efficiency is of great importance as a measure of capital allocation in the stock market, while the event study method can be used to examine whether the stock market absorbs new information quickly and accurately. In addition, event studies are also used to test the effectiveness of laws and regulations and to assess losses in legal cases.

Event studies have a long history, and it is common to think that James Dolley (1933) was the first to propose and use it in his study of common stock. He studied 57 stock splits between 1921 and 1931 in which the stock price increased at the time of the event, 26 in which the stock price decreased at the time of the event, and 12 in which the stock price did not change abnormally. Thereafter, during the last century Fama, Fisher, Jensen and Roll (FFJR) in 1969 extended the method almost to its today's form.

The event study method is not the only way to measure a company's value. One could also consider direct productivity related measures, sales, return on investment or profits. Although such measures could also be used in this research, they are only available at low frequencies (quarterly or annually), which makes it difficult to isolate the value-added of the event from the overall performance of the firm. For this reason, the event study method was chosen for this study, combined with the sales-growths measurements. The event study has its limitations as well, for instance, often the abnormal return estimators are crosssectionally correlated or are not independent across time for a given firm. However, in our case these problems are minor and can be ignored. Cross-sectional dependence is not a problem, as this paper only discusses one event, so the events are not clustered. The even period is rather short and market model abnormal returns estimates are used, which makes time series dependence unimportant.

The first step in our estimation is to choose the event. Our event is the Volkswagen Emissions Scandal. The day of the event can be difficult to define, as in some cases the scandal might break out before the official notice. To overcome this problem, the 'event window' that includes five days before and after the event is chosen. The 'estimation window' is needed for estimating the abnormal returns in 'normal' situations, without the event and defined as well. Usually, the estimation window time period is prior to the event. In this case, returns will be indexed in event time using t. Defining $\mathrm{t}=$ 
0 as the event date, $\mathrm{t}=T_{1} T_{1}+1$ to $\mathrm{t}=T_{2} T_{2}$ represents the event window with $T_{1} T_{1}$ indicating five days before the event $T_{2} T_{2}$ - five days after. Hence, the event date is the official violation notice, $\mathrm{s}=$ September 18,2015 , the event window includes September 11-25, 2015, meaning $T_{1}=$ September $11, T_{2}=$ September 25 .

$T_{1}=$ September 11, $T_{2}=$ September 25 . As for the estimation window, it is possible to choose any time period prior to the event, so a time period of 6 months is chosen, from February 18, 2015 to September 10, 2015. $\mathrm{t}=T_{0} T_{0}+$ 1 to $\mathrm{t}=T_{1} T_{1}$ constitutes the estimation window, therefore $T_{0}=$ February 18 . $T_{0}=$ February 18. The estimation window includes 143 days in total, ending a few days before the scandal period.

Next, Abnormal Return is defined as a difference between the expected return on stock $i$ at time $t$ and its actual return. For firm $i$ and event date $t$ the abnormal return is:

$$
\mathrm{AR}_{\mathrm{it}}=\mathrm{R}_{\mathrm{it}}-\mathrm{E}\left(\mathrm{R}_{\mathrm{it}} \mid \mathrm{X}_{\mathrm{t}}\right)
$$

where $A R_{i t}, R_{i t}$ and $E\left(R_{i t} \mid X_{t}\right)$ are the abnormal, actual, and normal returns respectively for time period $t$. $X_{\mathrm{r}}$ is the conditioning information for the normal return model. In this case the market model will be used, defining $X$ as the return of the market portfolio.

Formally, each stock's abnormal return can be measured by estimating the following regression:

$$
R_{i t}=\alpha_{i}+\beta_{i} R_{m_{t}}+\varepsilon_{i t}
$$

where $\mathrm{R}_{\mathrm{it}}$ is the actual return of firm $\mathrm{i}$ in the time period $\mathrm{t}, R_{m_{t}} R_{m_{t}}$ is the return on market portfolio, $\varepsilon_{i t} \varepsilon_{i t}$ is the error term, $\alpha_{i} \alpha_{i}$ and $\beta_{i} \beta_{i}$ are estimated parameters. To calculate the actual return, the formula is used:

$$
R_{i t}=P_{t} / P_{i t-1}-1
$$

which is the current value minus initial value of a stock and minus one.

Normal returns are estimated with the estimation window data using OLS regression. The next step is to use the parameters from equation (2) to estimate abnormal returns, in this case the data from the event window can be used:

$$
A R_{i t}=R_{i t}-\hat{\alpha}-\hat{\beta} R_{m t}
$$

It is also reasonable to aggregate the abnormal return observations in order to draw overall inferences for the event of interest. The sum of the 
abnormal returns of individual stocks over time is called the cumulative abnormal return (CAR), which is a measure of the impact of a scandal on a company's stock return. The CAR is defined by:

$$
C A R_{i t}=\sum_{t=t_{1}}^{t_{2}} A R_{i t}
$$

To test the null-hypothesis it is needed to conduct a significance test. The t-test is proposed, and p-value is calculated, to test the statistical significance of the results, using MacKinlay (1997) methods. For this purpose, the following formula is used:

$$
\frac{C A R_{i T}}{T * \operatorname{Var}\left[A R_{i}\right]^{\frac{1}{2}}}
$$

where $\mathrm{T}$ is the number of days in the event period, in our case including 11 days.

As one cannot be sure, whether the reputational spillovers will be positive or negative, two-sided tests are proposed. To test the statistical significance of Volkswagen's abnormal returns, the paper follows and employs a standard t-statistic. Since negative market reactions for Volkswagen are expected, one-sided tests can be used.

\section{Empirical Evidence}

\subsection{Data}

A few German automobile manufacturers were selected for the research. The final sample includes five companies: Volkswagen, Audi, Porsche, which all belong to Volkswagen group and probably will share the same reputational effects, and also BMW and Daimler (Mercedes-Benz). Stock prices of these companies during the estimation and event window period are collected from Bloomberg. Bloomberg L.P. is one of the two leading U.S. providers of financial information to professional financial market participants. The main product is Bloomberg Terminal, through which one can access current and historical prices on almost all world exchanges and many over-the-counter markets. As it has been already described before, the model used for the research is the market model, which requires market portfolio data. Here S\&P 350 is used - it's a stock index of European stocks. Using these two resources it is possible to calculate cumulative abnormal returns, which can measure a market value of a certain company.

Another part of our estimation is to compare the sales of each company in Europe and in China. Data on vehicle sales was provided by Wards Intelligence, a company, which specialises on auto industry information since 
1924, such as track and interpret market size, trends and movements, delivering forward-looking intelligence, statistics and insight.

Descriptive statistics of the sample is presented below:

Table 1. Descriptive Statistics

\begin{tabular}{llllll}
\hline Variable & Obs & Mean & Std. Dev. & Min & Max \\
\hline VW & 155 & 208.2 & 31.28 & 106 & 255.2 \\
Audi & 155 & 846.8 & 55.72 & 732.6 & 934.5 \\
BMW & 155 & 100.3 & 12.02 & 75.68 & 122.6 \\
Mercedes & 155 & 82.81 & 6.495 & 63.48 & 95.79 \\
Porsche & 155 & 76.80 & 11.14 & 40.74 & 94
\end{tabular}

Note: Note: Unit of observation is stock return. Time period covered is February 2015 to September 2015. Data comes from Bloomberg.

Table 1 offers an overview of the sample, which includes stock prices of 5 German automobile manufacturers during the period from February 17 till September 25 of 2015.

\subsection{Empirical Results \\ 5.2.1 Volkswagen}

First, consider the effects of the Volkswagen Emissions Scandal on Volkswagen itself. The regression results for each company during the event period are shown in Table 2. Figure 1 presents market reactions for Volkswagen's stocks during the scandal period, which includes 11 days (5 days prior to the official announcement of VW's cheating methods, the event day itself and 5 days after). Abnormal Returns are mostly negative but not significantly different from zero prior to the event. Post-announcement window demonstrates significant and negative abnormal returns, the CAR over the eleven days reached the value of $38 \%$. It is clear that VW's reputation suffered big losses due to the scandal. 
Table 2. Abnormal Returns during the event period

\begin{tabular}{llllll}
\hline Event Day & Volkswagen & Audi & Porsche & BMW & Mercedes \\
\hline-5 & .0006 & -.0012 & -.0052 & -.0071 & -.0064 \\
-4 & -.0027 & -.0010 & -.0007 & .0015 & .0109 \\
-3 & .0146 & .0705 & .0139 & .0252 & .0157 \\
-2 & .0043 & -.0011 & .0208 & .0042 & .0035 \\
-1 & -.0100 & -.0012 & -.0087 & .0094 & .0016 \\
0 & -.0317 & -.0013 & -.0307 & -.0303 & -.0449 \\
1 & -.1844 & -.0674 & -.1705 & -.0136 & -.0133 \\
2 & -.1955 & -.1279 & -.1693 & -.0556 & -.0663 \\
3 & .0527 & .0080 & .0195 & .0056 & .0015 \\
4 & .0093 & .0506 & -.0022 & -.0446 & -.0379 \\
5 & -.0418 & -.0011 & -.0301 & .0436 & .0357 \\
\hline
\end{tabular}

Note: Unit of observation is the daily abnormal stock return. Abnormal returns are calculated using the market model (equation (4)). Automotive stock prices come from Bloomberg. Event Day period includes 5 days prior to the event, the event day and 5 days after, from September 11 to September 25 (some days were not working days).

Figure 1. Volkswagen's Abnormal Returns in the Event Window

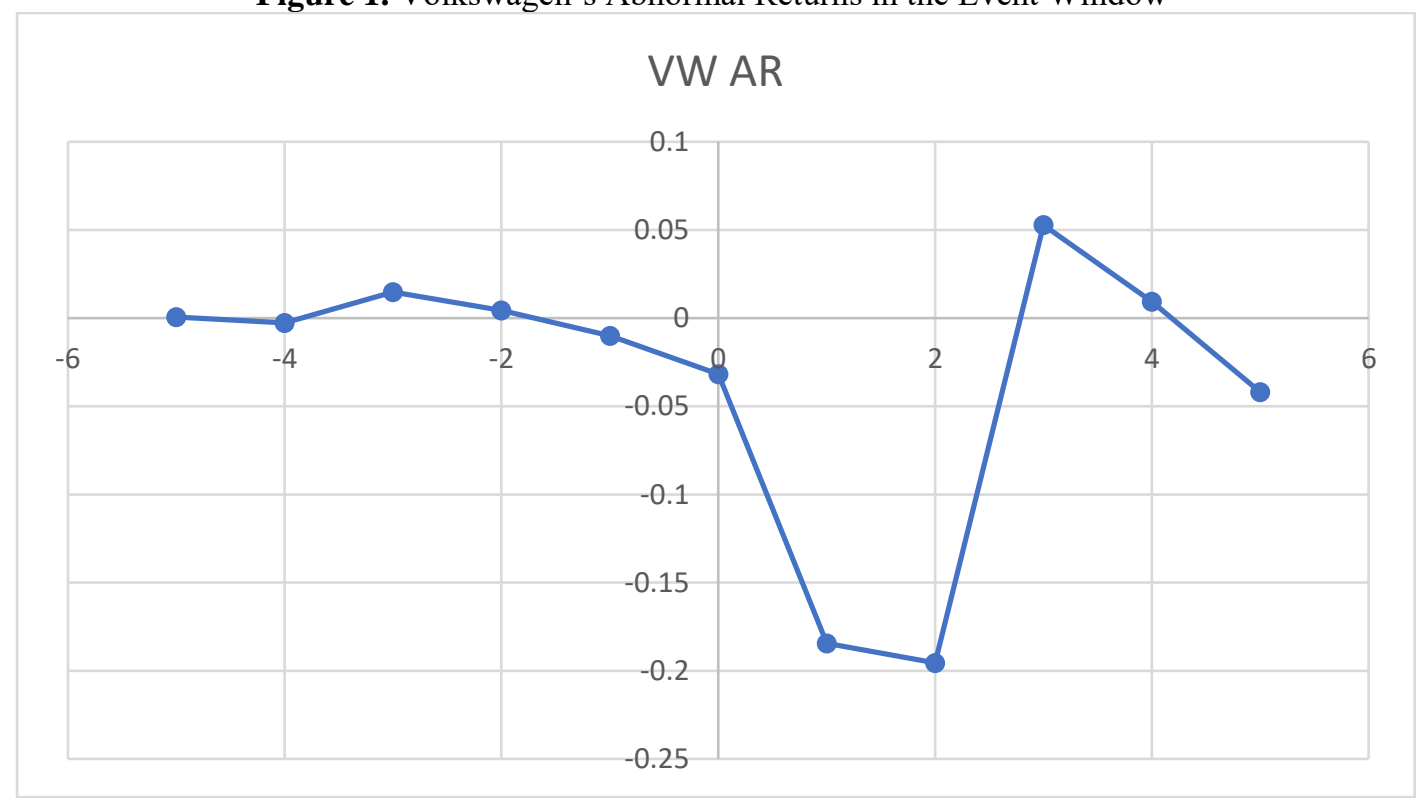

Note: 0 marks the event day of the VW emissions scandal (September 18, 2015) Automotive stock data come from the Bloomberg database.

The second important point of our study is comparison of companies' performance in two different regions: Europe and China. Next, look at Volkswagen's sales growth on these two markets by year, from 2011 to 2020. Figure 2 shows the results, which are similar to abnormal returns' trend, VW's sales growth in the event year (2015) is significantly declined in China and declines slowly but steady in Europe. 
An interesting trend on Figure 2 shows that Volkswagen was able to recover its sales in 2016, the year after the event, followed by a slow decline in the next few years. Comparing China and Europe, the decline in sales growth and further recovery are both much sharper in China and relatively smooth in Europe. This might mirror the society's reaction to the Emissions Scandal.

Figure 2. Volkswagen's Sales Growths in Europe and in China

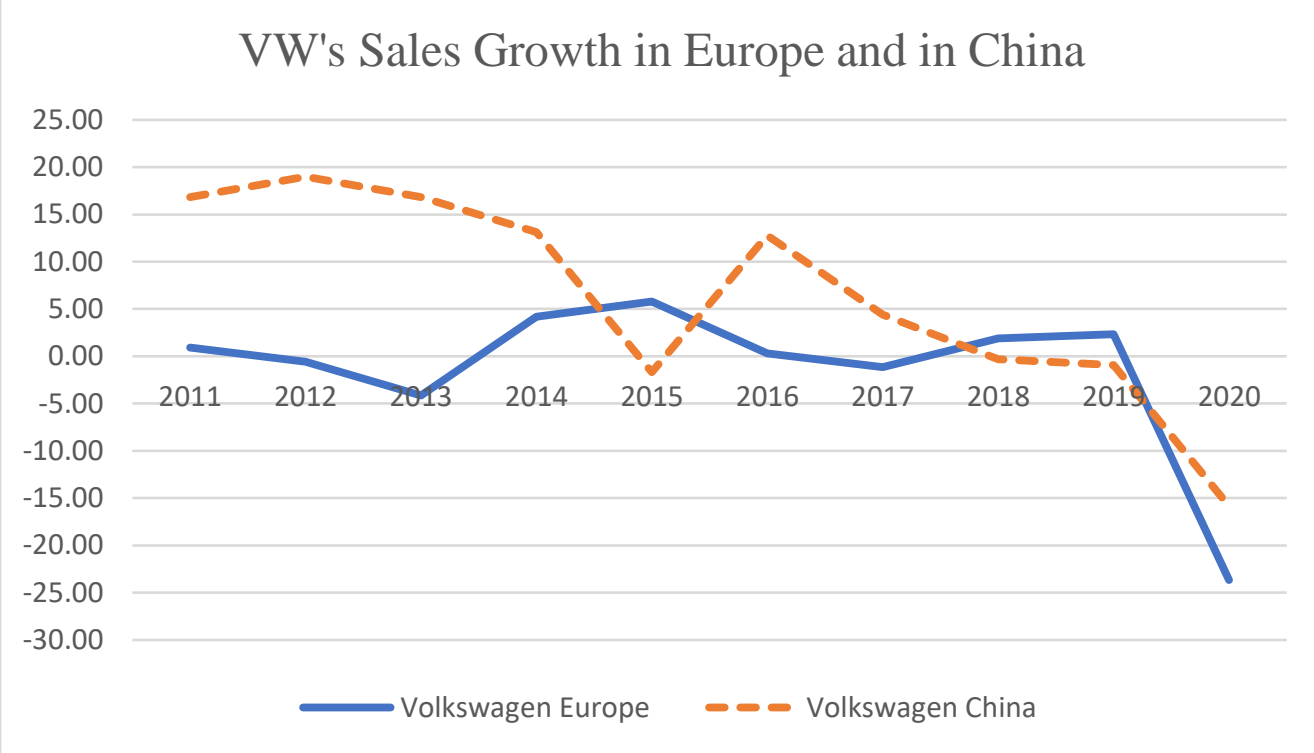

Note: Dashed line shows the sales growth of VW in China, calculated using equation (7), solid line shows VW's sales growth in Europe, yearly data come from Ward's Automotive and covers the time period from 2011 to 2020 .

In the next section reputational spillover effects for rival companies are considered, examining cumulative abnormal returns for each firm and sales growths by year in two regions.

\subsubsection{Rival firms' stock price}

After performing a regression using the event study method described above with formulas (1) to (5), abnormal returns are examined separately for each manufacturer. The abnormal returns for each firm, including both Volkswagen Group (VW, Audi and Porsche) and 2 rival firms (BMW, Mercedes-Benz), are shown in Table 3. First, the mean results of abnormal returns are summarized, it is clear that all five manufacturers received a negative impact from the scandal (the result for Audi turned out not to be significant, which might be explained by data limitations). 
Table 3. Abnormal Returns Statistic

\begin{tabular}{cccccc}
\hline Variable & Obs & Mean & Std. Dev. & Min & Max \\
\hline VW_return & 154 & -.0039 & .0293 & -.1955 & .0588 \\
Audi_return & 154 & .0006 & .0179 & -.1279 & .0715 \\
BMW_rreturn & 154 & -.0016 & .0197 & -.0556 & .0635 \\
Mercedes_return & 154 & -.0012 & .0201 & -.0663 & .0578 \\
Porsche_return & 154 & -.0038 & .0263 & -.1721 & .0498
\end{tabular}

Note: Descriptive statistics of the daily abnormal stock returns observations. Abnormal returns are calculated using a market model (equation (4)). Automotive stock prices come from Bloomberg. The time period includes both, Event Window and Estimation Window, from February, 2015 to September, 2015.

This paper examines Total Abnormal Returns, to have an overview of the companies' stocks during each day of the event period. Total Abnormal Returns are obtained by summing all the AR during the event window. As a result, there is an obvious reduction in companies' abnormal returns on the event day and the following day as well. The results are summarized in Table 4.

According to our null-hypothesis, when AR are equal to zero, there is no reputational spillover effect on other firms from the same industry. The null-hypothesis can be rejected, as from the Table 4 ARs are close to zero a few days before the event, but on the event day (day 0) and the following two days there is a significant decline in Abnormal Returns, proving a negative spillover effect - the contagion effect, of Volkswagen Emissions Scandal on rival German automobile manufacturers. Figure 3 demonstrates Total Abnormal Returns during the event period visually.

Table 4. Total Abnormal Returns

\begin{tabular}{ccccc}
\hline Event Day & TAR & Std.Dev & t-statistic & p-value \\
\hline-5 & -.0195 & .0034 & -5.790 & $4.3848 \mathrm{E}-08 * * *$ \\
-4 & .0080 & .0054 & 1.473 & 0.142713166 \\
-3 & .1402 & .0242 & 5.798 & $4.2261 \mathrm{E}-08 * * *$ \\
-2 & .0319 & .0084 & 3.806 & $0.000209798 * *$ \\
-1 & -.0090 & .0080 & -1.125 & 0.26245983 \\
0 & -.1319 & .0160 & -8.687 & $8.4244 \mathrm{E}-15 * * *$ \\
1 & -.4493 & .0830 & -5.409 & $2.6465 \mathrm{E}-07 * * *$ \\
2 & -.6148 & .0616 & -9.980 & $4.5020 \mathrm{E}-18 * * *$ \\
3 & .0876 & .0207 & 4.212 & $4.4952 \mathrm{E}-05^{* * *}$ \\
4 & -.0247 & .0386 & -.6419 & 0.521959085 \\
5 & .0062 & .0382 & .1630 & 0.870753836 \\
\hline
\end{tabular}

Note: Unit of observation is total abnormal returns, the sum of abnormal returns during the event period (September 11-25, 2015). Significant levels: *(p<0.10), **(p<0.05),***(p< $0.01)$. 
Figure 3. Total Abnormal Returns during the event period.

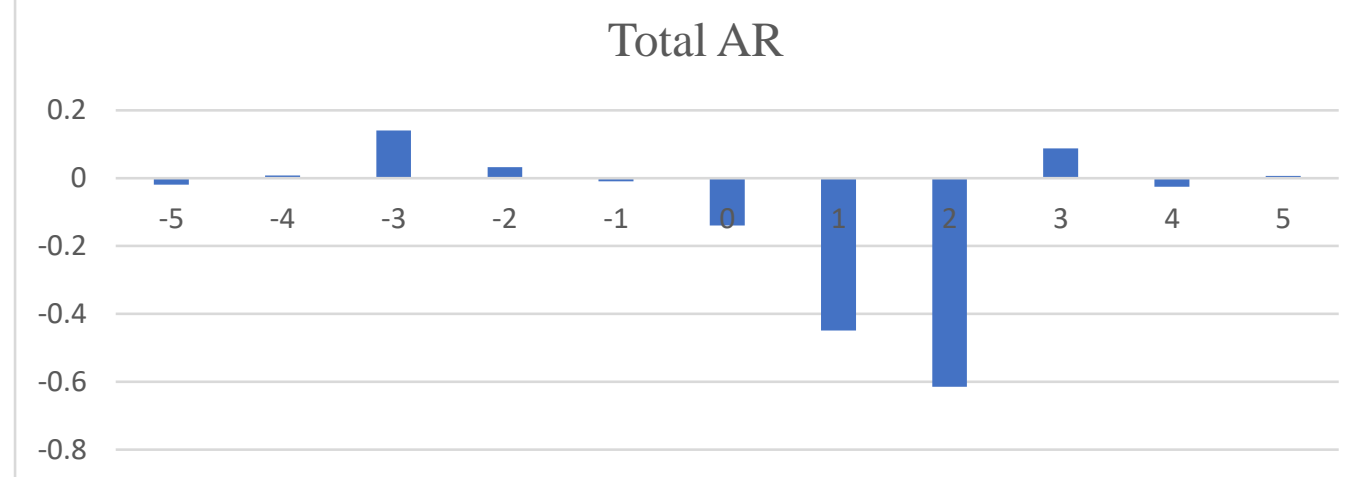

Note: 0 is September 18 (the event day).

It can also be noted that the scandal was rather surprising for the stockholders, as prior to the event the stock returns were stable. The day after the bad news broke, total abnormal stock returns for our sample companies declined by $45 \%$, and on the day after - by $60 \%$. The results for the event day and three days after are statistically significant.

After the AR of individual stocks in the event window are calculated, they are summed to obtain the cumulative abnormal return CAR, from which the effects of scandalous events on listed companies in the same industry can be examined. The results of the regression and the two-sided significance test are shown in Table 5:

Table 5. Cumulative Abnormal Returns

\begin{tabular}{ccccc}
\hline Company & CAR & Std.Dev. & t-statistic & p-value \\
\hline Volkswagen & -.3825 & .0805 & -4.752 & $4.89 \mathrm{E}-06 * * *$ \\
Audi & -.0733 & .0529 & -1.384 & .1686 \\
Porsche & -.3635 & .0698 & -5.206 & $.0369 * *$ \\
BMW & -.0617 & .0293 & -2.106 & $.0010^{* * *}$ \\
Mercedes-Benz & -.0997 & .0297 & -3.355 & $6.67 \mathrm{E}-07 * * *$ \\
\hline
\end{tabular}

Note: Unit of observation is the cumulative abnormal returns for the periods before and after the event date. Abnormal returns are calculated using a market model (equation (2)). Automotive stock prices come from Bloomberg. The pre-scandal period comprises September $11,14,15,16$ and 17, 2015, and the post-scandal period comprises September 21, 22, 23, 24 and 25, 2015 (Some days are missing for the reason that there are no trades on weekends). Significant levels: $*(\mathrm{p}<0.10), * *(\mathrm{p}<0.05), * * *(\mathrm{p}<0.01)$.

The results are mostly statistically significant (except for Audi), and all of the five German automobile manufacturers show negative cumulative abnormal returns. Three of these companies (Volkswagen, Audi and Porsche) belong to Volkswagen Group. In Table 5 rival firms (BMW and MercedesBenz) experienced a reputational spillover, and the results show the dominance of contagion effect. Volkswagen and Porsche, as both members of the Volkswagen Group, show 38\% and 36\% percent decline in stock returns 
during the event period, which is a significant number. Whereas BMW and Mercedes-Benz, as VW's rivals, show $6 \%$ and $10 \%$ abnormal returns decline respectively, showing the contagion effect, but scientifically smaller than the loss, experienced by VW Group itself. This evidence suggests that the Volkswagen Emissions Scandal brought financial harm not only to the company itself, but also to the German rival firms.

\subsubsection{Rival firms' Sales Growth}

To compare reputational spillover of German car manufacturers in Europe and in China this paper calculates their sales growths in China and in Europe during the time period from 2011 to 2020 using unit sales data, presented in Table 6 and calculated by the following equation:

Sales Growth Rate $=($ Current Period Sales - Prior Period Sales $) /$ Prior Period Sales *100

Table 6. Sales Growth Yearly in Europe and in China (\%)

\begin{tabular}{ccccccccc}
\hline Year & \multicolumn{2}{c}{ Volkswagen } & \multicolumn{2}{c}{ Audi } & \multicolumn{2}{c}{ BMW } & \multicolumn{2}{c}{ Mercedes } \\
\hline & Europe & China & Europe & China & Europe & China & Europe & China \\
\hline & & & & & & & & \\
2011 & 0.93 & 16.83 & 9.94 & 26.19 & 6.55 & 59.03 & 1.01 & 47.76 \\
2012 & -0.56 & 18.99 & 1.70 & 27.64 & -1.41 & 51.61 & -0.04 & 14.14 \\
2013 & -4.15 & 16.85 & -1.36 & 25.26 & -0.17 & 37.47 & 4.44 & 25.53 \\
2014 & 4.17 & 13.14 & 3.91 & 24.60 & 5.12 & 34.18 & 5.19 & 12.87 \\
2015 & 5.79 & -1.66 & 5.63 & -0.59 & 10.57 & 3.17 & 12.33 & 82.98 \\
2016 & 0.31 & 12.78 & 8.41 & 5.16 & 9.88 & 8.01 & 13.69 & 27.98 \\
2017 & -1.14 & 4.42 & -0.46 & 2.39 & 0.82 & 24.14 & 7.98 & 36.43 \\
2018 & 1.90 & -0.30 & -13.33 & 12.96 & -0.76 & 20.84 & -3.13 & 15.13 \\
2019 & 2.35 & -0.93 & 3.77 & -0.05 & 0.94 & 17.09 & 3.25 & 16.05 \\
2020 & -23.66 & -15.84 & -18.76 & 5.80 & -18.34 & 12.40 & -17.36 & 7.60 \\
\hline
\end{tabular}

Note: Unit of observation is sales growth in unit sold, observations for China only include domestic production and doesn't include imported cars.

Regarding the sales growth, values in Europe and in China appear to be different. Table 6 shows the sales-growth in percentage points for unit sold for four German car companies (Porsche is excluded from the analyses due to lack of data), Volkswagen and Audi, as both members of the Volkswagen Group, show increasing sales in China during the period from 2011 up until the scandal in 2015. In Europe the numbers show much smaller values and even negative in 2013 for most of the companies. Starting from 2015 the situation changed dramatically: sales growths in China for Volkswagen and Audi fell by $15 \%$ and $25 \%$ respectively, BMW sales fell by $31 \%$ in 2015 . Surprisingly, Mercedes-Benz shows a great increase in sales growth in China, its sales growth rate increased from roughly $13 \%$ in 2014 to $83 \%$ in 2015, indicating 
possible competitive effect of reputational spillover. Similar to this, Mercedes also increased its sales growth in Europe by 7\%, BMW showed an increase of $5 \%$ in 2015, Audi increased its sales growth in Europe as well by almost 2\% in 2015 and once again 3\% in 2016. Volkswagen was able to regain its sales volume growth in China in 2016 back to almost $13 \%$ with the help of new car models, whereas in Europe that year the sales were extremely law after the scandal

The following years, Volkswagen sales growth remained rather low both, in Europe and in China. Audi recovered partly in 2018, but still, the sales growth rate is far different from the one in the previous years in 2011-2014 in China. However, the rival firms show an interesting trend, and both BMW and Mercedes-Benz still have a high sales growth rate in China, even though the Corona Crises brought large difficulties to all the manufacturers. This proves that while the Volkswagen Group was struggling to regain its reputation, rival firms were taking over the market share both in China and in Europe.

To exclude exogenous factors and test what effect the Volkswagen Emissions Scandal had on the sales growths of German car manufacturers, the difference-in-differences (DiD) regression approach can be used. This method is based on a combination of before-after and treatment-control group comparisons and is one of the most frequently used methods in impact evaluation studies (Fredriksson, 2019; Lee and Sawada, 2020). DiD method strongly relies on the parallel trends assumption, which states that the treatment group, absent the reform, would have followed the same time trend as the control group. It is therefore rather difficult to choose a suitable control group. This paper used sales data for several non-German automobile manufacturers as the control group that were chosen based on the parallel trend assumption. Selected firms are presented in Table 7.

Table 7. Sales Growth Sample Companies

\begin{tabular}{ccc}
\hline Audi & Ford & Morgan \\
Baojun & Geely & Mercedes-Benz \\
Bestune & Haima & Nissan \\
BMW & Honda & Opel \\
Buick & Hyundai & Peugeot \\
Chevrolet & JAC & Renault \\
Citroen & Jeep & Subaru \\
Dongfeng & Kia & Suzuki \\
FAW & Lifan & Toyota \\
Ferrari & Mazda & Volkswagen \\
Fiat & Mitsubishi & Volvo \\
\hline
\end{tabular}

Note: Data is obtained from Ward's Automotive, it includes German and non-German automobile manufacturers from different countries.

The coefficients are estimated separately for each treated firm (VW, Audi, BMW and Mercedes) to compare the differences of the reputational 
spillover effect on every company and also to see the effect for VW Group itself. The following equation is used for difference-in-differences estimation:

$$
y_{i t}=\alpha+\beta_{i}+\gamma_{t}+\delta T_{i t}+\varepsilon_{i t}
$$

where $y_{i t} y_{i t}$ is company's $i$ sales growth rate at the time $t, \beta_{i} \beta_{i}$ is company's fixed effect, taking value 1 if it's a treated company (German car manufacturer) and 0 for non-German manufacturers, $\gamma_{t} \gamma_{t}$ is time fixed effect, taking value 1 during the even time (2015-2016), $T_{i t} T_{i t}$ is an indicator taking value 1 for German automobile manufacturers during the event time, ${ }^{\varepsilon_{i t}} \varepsilon_{i t}$ is the error term. The results of the DiD regression are shown in Table 8. Panel A stands for sales growth in Europe and Panel B shows values in China.

Table 8. Difference-in-differences estimation results: German vs. non-German manufacturers

\begin{tabular}{cccc}
\hline Company & DiD & z-statistic & p-value \\
\hline Panel A: Europe & & & \\
Volkswagen & -.0383 & -2.69 & $.007^{* * * *}$ \\
& $(.0142)$ & & \\
Audi & -.0157 & -1.10 & .270 \\
& $(.0142)$ & & .587 \\
BMW & .0077 & 0.54 & \\
& $(.0142)$ & & $.001^{* * *}$ \\
Mercedes-Benz & .0493 & 3.47 & \\
& $(.0142)$ & & .399 \\
Panel B: China & & & \\
Volkswagen & -.0524 & -0.84 & $.021^{* * *}$ \\
& $(.0621)$ & & $.000^{* * *}$ \\
Audi & -.1430 & -2.30 & \\
& $(.0621)$ & & $.001^{* * * *}$ \\
BMW & -.2524 & -4.06 & \\
\hline
\end{tabular}

Note: Unit of observation is sales growth in units sold, observations for China only include domestic production and don't include imported cars. Control groups for DiD estimation include non-German car manufacturers based on parallel trends assumption. Panel A presents results for sales growth in Europe, Panel B shows the results for China. Standard errors clustered at vehicle level in parentheses. Data comes from Ward's Automotive. Time period 
includes annual sales from 2000 to 2019 for Europe and from 2011 to 2019 for China. Significant levels: $*(\mathrm{p}<0.10), * *(\mathrm{p}<0.05), * * *(\mathrm{p}<0.01)$.

Overall effect in China is much greater than in Europe. These results show that reputational spillovers, competitive and contagion effects, depend not only on the rival firms' size and competitive abilities, but also on geographical locations. The effects for the same companies differ in Europe and in China due to external factors, such as market's features and consumers' preferences and psychology.

The DiD coefficients are negative for Volkswagen and Audi in both regions, Europe and China, which indicates sales growth drop for Volkswagen Group after the scandal. Volkswagen's sales growth dropped by 5\%. Audi showed no significant effect in Europe, but a 14\% decrease in China. BMW experienced a negative spillover effect greatly in China, where its sales growth decreased by $25 \%$, on the contrary, it increased in Europe, although this result is not significant. Mercedes-Benz, on the other hand, experienced a significant positive effect both in Europe and in China, increasing its sales growth by $5 \%$ and $20 \%$ respectively.

\subsection{Discussion}

The results illustrate that the Volkswagen Emissions damaged not only VW's reputation, but negatively affected the whole German automotive industry as well. When rival firms are not able to effectively differentiate themselves from the fraudulent firm, they are more likely to suffer contagion effects of the reputational spillovers (Ouyang et al., 2020). Companies' different strategies on European and Chinese markets can help the differentiation. BMW experienced different effects on the European and Chinese market, indicating that its strategy was more successful and more suitable for the European market. Mercedes-Benz, on the other hand, was able to increase its sales on both markets, as its reputation was less damaged despite the scandal, possibly due to its successful business model and differentiation from Volkswagen.

As Zhang and Schweiger (2009) stated in their study, social responsibility is the second strongest driver of corporate reputation in China. When the Emissions Scandal became public, it was clear that Volkswagen showed its lack of responsibility for public health and ecological situation in the world, losing trust of Chinese consumers. Although the sales growth reduced in Europe as well, the scale in China was much larger, compared to European countries. Mercedes-Benz, on the other hand, showed a strong competition effect, increasing its sales in China during the scandal period. It also proves that with good marketing strategies, successful differentiation and 
management a company can increase its chances of gaining from the scandal, rather than receiving a contagion effect.

Although Volkswagen experienced a negative effect of the Emissions scandal on its sales and stock price, it was still able to keep its sales high in China, especially in 2016. It can be explained by VW's strength in the Chinese market, which can be linked to the company's long-standing relationship with the country's car buyers. In addition, the brand's Chinese offerings are almost exclusively gasoline powered. This means that VW's operations in the country were not really exposed to the 2.0-liter, diesel, four-cylinder engine at the heart of the scandal that affected more than 11 million cars worldwide. It can be assumed that once consumers realised that the scandal only refers to diesel cars, the sales volume went back to rising. Another reason is China's tax cut on small-engine cars in 2016, but growth was expected to slow in 2017 as the incentive is reduced (Reuters, 2017).

The question remains, why is there a difference in companies' reaction to the Emissions scandal? For Mercedes-Benz 2015 was the most successful year in the history of the company, its sales in China rapidly increased, nearly taking over the market. According to its annual report, this growth might be explained by Mercedes' product offensive strategy, where the brand aimed to launch various new models before the end of the decade and to become the world's largest premium automaker. This also warranted large amounts of investment in research and development, and capital expenditure, to expand the production footprint. While large costs had kept Mercedes' margins subdued till a couple of years back, the benefits of efficiency programs, the higher price of new models, and more volume sales, have boosted the brand's profitability more recently (Daimler, 2015). Evidently, with effective crisis management and strong competitive ability, it is more likely for a company to enjoy a competitive effect of reputational spillover, rather than a contagion effect. This evidence might be of use for rival firms in planning sales strategy and competition strategy as well.

\section{Conclusion}

This paper investigates the reputational spillover effect on the rival firms from the same industry, using the Volkswagen Emissions Scandal case as a natural experiment. The research considered Volkswagen Group, represented by Volkswagen, Audi and Porsche, and other German automobile manufacturers, represented by BMW and Mercedes-Benz. Using the event study method the results find that all the German car companies suffered from a negative impact of the scandal, which is shown by negative cumulative abnormal returns, although the effects were much smaller for BMW and Mercedes-Benz. This result proves the contagion effect of the reputational spillover. The paper also conducted a comparison of the four firms' sales 
growth in Europe and in China, followed by the difference-in-differences estimation, and find that the negative effect for the Volkswagen Group was even larger in China, but Mercedes-Benz was able to gain from the scandal and increased its sales growth in China in 2015-2016 (scandal period). These results are in line with our theoretical hypothesis: firstly, rival firms from the same industry will experience either competitive or contagion effects; secondly, the effects in China and in Europe will differ, due to special features of the countries and their consumers.

This paper contributes to the literature by providing empirical support for the theoretical literature on collective reputation. Our results suggest that policy makers as well as companies' managers could make some steps in addressing collective reputation, which might help large companies to internalize their potential reputation spillovers. This paper argues that some companies, for example, Mercedes, were able to gain from the scandal, which gives policy makers the evidence that with the right management it is possible not only to avoid negative effects of the reputational spillovers, but also to benefit from it, receiving a competition effect. The results also find that there are geographical differences regarding the spillover effects, therefore it can be suggested to the policy makers to consider local consumers' psychology and market's characteristics when developing a strategy.

However, the research has several limitations that offer opportunities for future research. In this paper only stock returns and the sales growth rate are compared across countries, which might not be a perfect way of measuring a company's reputation. Other methods of measuring corporate reputation also exist, for example, a new developed method via social media reaction (Rust, 2021). The results might differ, depending on the research method and considered factors (stock price, bonds, sales growth, social reaction, CDS etc.). Another problem is the sample size, as this research considers only German car manufacturers, their number is rather small, which limits the companies sample size to only five major manufacturers. Future research could possibly focus on another industry that would offer a larger sample size and more variety for investigating reputational spillovers.

Corporate reputation and reputational spillovers are a very discussed topic in existing literature, but researchers mostly focus on a company's stock price and often ignore possible geographical differences. This paper suggests that future research could focus on rival firm's performance on different markets, comparing contagion and competitive effects for the same companies across different countries. 


\section{References:}

1. Akhigbe, A. \&Martin, A.D. (2000). Information-signaling and competitive effects of foreign acquisitions in the US. Journal of Banking \& Finance, 24(8), pp.1307-1321.

2. Akhigbe, A., Madura, J. \&Martin, A.D. (2015). Intra-industry effects of negative stock Price surprises. Review of Quantitative Finance and Accounting, 45(3), pp.541-559.

3. Barth, F., Eckert, C., Gatzert, N. \&Scholz, H. (2019). Spillover Effects from the Volkswagen Emissions Scandal: An Analysis of Stock, Corporate Bond, and Credit Default Swap Markets. SSRN Electronic Journal: $\quad$ https://ssrn.com/abstract=3089897 or http://dx.doi.org/10.2139/ssrn.3089897

4. Boone, A. \& Uysal, V. B. (2020). Reputational concerns in the market for corporate control. Journal of Corporate Finance, 61(C).

5. Bouzzine Y.D. \& Lueg R. (2020). The contagion effect of environmental violations: The case of Dieselgate in Germany. Business Strategy and the Environment, 29(8), pp.3187 - 3202.

6. Chen, S-S., Ho, K.W. \&Ik, K.H. (2005). The wealth effect of new product introductions on industry rivals. The Journal of Business, 78(3), pp.969-996.

7. Chen, Y., Lin Lawell, C.-Y. C. \& Wang, Y. (2020). The Chinese automobile industry and government policy. Research in Transportation Economics, Elsevier, vol. 84(C).

8. Dolley, J. (1933). Characteristics and Procedure of Common Stock Split-Ups. Harvard Business Review, 11, pp.316-26.

9. Eckert, C., Gatzert, N. \&Heidinger, D. (2020). Empirically assessing and modeling spillover effects from operational risk events in the insurance industry. Insurance: Mathematics and Economics, 93, pp.72-83,

10. Elliott, R.S., Highfield, M.J. \&Schaub, M. (2006). Contagion or competition: going concern audit opinions for real estate firms. Journal of Real Estate Finance and Economics, 32(4), pp.435-448.

11. Fama, E.F., Fisher, L., Jensen, M.C. \&Rol, R. (1969). The Adjustment of Stock Prices to New Information. International Economic Review, 10(1), pp.1-21.

12. Fredriksson, A. \&Oliveira, G.M.d. (2019). Impact evaluation using Difference-in-Differences. RAUSP Management Journal, 54(4), pp. 519-532.

13. Freyaldenhoven, S., Hansen, C. \&Shapiro, J.M. (2019). Pre-event Trends in the Panel Event-Study Design. American Economic Review, 109 (9), pp.3307-3338. 
14. Goins, S. \&Gruca, T. (2008). Understanding Competitive and Contagion Effects of Layoff Announcements. Corporate Reputation Review, 11, pp. 12-34.

15. Helwege, J. \&Zhang, G. (2015). Financial Firm Bankruptcy and Contagion. Review of Finance, 20(4), pp.1321-1362

16. Hu, Z. \&Yuan, J. (2018). China's NEV market development and its capability of enabling premium NEV: Referencing from the NEV market performance of BMW and Mercedes in China. Transportation Research Part A: Policy and Practice, 118, pp.545-555.

17. Joshi, B. R. (2019). Trend in Asian and European Automobile Industry and its Challenges. International Journal of Business and Administrative Studies, 5(6), pp.321-328.

18. Jung, J. \&Sharon, E. (2019). The Volkswagen emissions scandal and its aftermath. Global Business and Organizational Excellence,38, pp. 6-15.

19. Klier, T. \&Linn, J. (2016). Comparing US and EU Approaches to Regulating Automotive Emissions and Fuel Economy. Policy Brief, 16-03, pp. 1-9.

20. Lang, L.H.P. \&Stulz, R.M. (1992). Contagion and competitive intraindustry effects of bankruptcy announcements: an empirical analysis. Journal of Financial Economics, 32(1), pp.45-60

21. Laux, P., Starks, L.T. \&Yoon, P.S. (1998). The relative importance of competition and contagion in intra-industry information transfers: an investigation of dividend announcements. Financial Management, 27(3), pp. 5-16

22. Le Page, M. (2015). How did Volkswagen rig emissions tests? New Scientist, 227(3041), p. 11.

23. Lee, M. \&Sawada, Y. (2020). Review on Difference in Differences. The Korean Economic Review, 36(1), pp.135-173.

24. MacKinlay, A. C. (1997). Event Studies in Economics and Finance. Journal of Economic Literature, 35(1), pp. 13-39.

25. Mansouri, N. (2016). A Case Study of Volkswagen Unethical Practice in Diesel Emission Test. International Journal of Science and Engineering Applications, 5, pp. 211-216.

26. Ouyang, Z., Yao, C. N., \& Hu, X. (2020). Crisis spillover of corporate environmental misconducts: The roles of perceived similarity, familiarity, and corporate environmental responsibility in determining the impact on oppositional behavioral intention. Business Strategy and the Environment, 29(4), pp.1797-1808.

27. Pappu, R., Quester, P.G. \&Cooksey, R.W. (2007). Country image and consumer-based brand equity: Relationships and implications for 
international marketing. Journal of International Business Studies, 38, pp. 726-745.

28. Paruchuri, S., Pollock, T. \& Kumar, N. (2019). On the tip of the brain: Understanding when negative reputational events can have positive reputation spillovers, and for how long. Strategic Management Journal. 40(12), pp.1965-1983.

29. Rust, R.T., Rand, W., Huang, M-H., Stephen, A.T., Brooks, G. \&Chabuk, T. (2021). Real-Time Brand Reputation Tracking Using Social Media. Journal of Marketing, 85(4), pp. 21-43.

30. Schwaiger, M. (2004). Components and Parameters of Corporate Reputation - An Empirical Study. Schmalenbach Business Review, 56(1), pp. 46-71.

31. Scurlock, R., Dolsak, N. \& Prakash, A. (2020). Recovering from Scandals: Twitter Coverage of Oxfam and Save the Children Scandals. Voluntas 31, pp. 94-110.

32. Slovin, M.B., Sushka, M.E. \&Polonchek, J.A. (1999). An analysis of contagion and competitive effects at commercial banks. Journal of Financial Economics, 54(2), pp. 197-225.

33. Tawatnuntachai, O. \&D'Mello, R. (2002). Intra-industry reactions to stock Split announcements. Journal of Financial Research, 25(1), pp.39-57.

34. Vošta, M. \&Kocourek, A. (2017). Competitiveness of the European Automobile Industry in the Global Context. Politics in Central Europe, 13(1), pp.69-86.

35. Wood, L. C., Wang, J. X., Duong, L. N. K., Reiners, T., \& Smith, R. (2018).

36. Stock market reactions to auto manufacturers' environmental failures.

37. Journal of Macromarketing, 38(4), pp. 364-382.

38. Xie, P., Wu, J. \&Du, H. (2019). The relative importance of competition to contagion: evidence from the digital currency market. Financial Innovation, 5(41), p.19.

39. Zhang, Y. \&Schwaiger, M. (2009). An empirical research of corporate reputation in China, Schriften zur marktorientierten Unternehmensführung. Working Paper No. 4, Ludwig-MaximiliansUniversität München, Institut für Marktorientierte Unternehmensführung, München.

40. Zhao, J. \&Gao, L. (2009). How to be Competitive in Chinese Automobile Industry. International Journal of Economics and Finance,1(2), pp.144-148.

41. Daimler (2015). Annual Report 2015. Retrieved April 4, 2021 from https://www.daimler.com/documents/investors/berichte/geschaeftsber ichte/daimler/daimler-ir-annual-report-2015.pdf 
42. EPA (2015a). Notice of Violation, Washington, D.C., United States. Retrieved April 22, 2021 from http://www.epa.gov/sites/production/files/2015-10/documents/vwnov-caa-09-18-15.pdf

43. EPA (2015b). Notice of Violation, Washington, D.C., United States. Retrieved April 22, 2021 from http://www.epa.gov/sites/production/files/2015-11/documents/vwnov-2015-11-02.pdf

44. Reuters (2017). China vehicle sales to grow 5 percent in 2017 as tax cut reduced, https://www.reuters.com/article/us-china-autos-salesidUSKBN14W0T6

45. VW (2015a). Statement of Prof. Dr. Martin Winterkorn, CEO of Volkswagen AG, Wolfsburg, Germany,

46. http://www.volkswagenag.com/en/news/2015/9/statement_ceo_of_vo lkswagen_ag.html, accessed: 02/13/2018.

47. VW (2015b). Ad hoc: Volkswagen AG has issued the following information, Wolfsburg, Germany. http://www.volkswagenag.com/en/news/2015/9/Ad_hoc_US.html, 